\title{
Economic Limits of (de)Regulation in Legal Services Market
}

\author{
Franjo Mlinaric ${ }^{1}$, Zan Jan Oplotnik ${ }^{1}$, Bostjan Brezovnik ${ }^{2}$
}

\author{
${ }^{1}$ University of Maribor \\ Razlagova 14, SI-2000, Maribor, Slovenia \\ E-mail.franjo.mlinaric@um.si,zan.oplotnik@um.si \\ ${ }^{2}$ University of Maribor \\ Mladinska ulica 9, 2000 Maribor, Slovenia \\ E-mail.bostjan.brezovnik@um.si
}

cross $^{\text {ref }}$ http://dx.doi.org/10.5755/j01.ee.29.3.19826

\begin{abstract}
Deregulation of professional services is universally praised for assisting lower prices, higher quality, and faster innovation pace benefiting the public. However, major authorities in economic science (from A. Smith to R. Coase) agreed that efficient regulation is needed to reduce frictions and promote trade. Particularly legal services demonstrate numerous forms of inefficiencies, requiring a thorough microeconomic evaluation before optimising the regulation. The highly polarised market is split in two segments with regulation mostly needed at its bottom. Our longitudinal study of Slovenian legal offices population mainly rejects the private capture hypothesis and exposes political risks of regulation, which might lead to the "tragedy of commons". Imposed lawyer's tariff freeze since 2003 paradoxically hurts the pillars of a network warranting physical and economic accessibility of legal services for most vulnerable groups. We estimate that the lawyer's tariff in Slovenia is undervalued almost by half, but only a slow increase can be expected due to political costs and fiscal effects. Dismal perspectives for lawyer's profession divert capable new entrants to start the career, causing long-term gap in labour supply. Thus, we concentrated on modelling the minimum requirements for a financially viable network coverage in order to support positive externalities.
\end{abstract}

Keywords: Legal Services; Regulated Prices; Public Services; Information Asymmetry; Financial Viability.

\section{Introduction}

Theoretically, free markets are able to provide the most efficient allocation of resources without any regulatory intervention, thus maximising social welfare. However, efficient market assumptions might be unfulfilled for reasons like information asymmetry, externalities or public good status that are inherent for legal services. Adequate regulation was acceptable even for Coase (1988) who stated that regulations “...exist in order to reduce transaction costs and therefore to increase the volume of trade". Moreover, there is a rare harmony among various leading economists that perfect market efficiency should not be simply assumed, but should be supported with a proper level of regulation (Smith, 2017; Friedman, 1962; Akerlof, 1970).

Arrow (1963) managed to demonstrate that prudent regulation is a fundamental prerequisite for sustainable economic growth and general social welfare in the specific health care market. He proved its systemic and persistent impact on human behaviour; but its positive externalities are less visible when we become used to high standards. Thus, a deregulation wave can appear politically promising without a proper economic analysis checking for potential welfare losses in a cost-benefit summary. Financial services markets after 2007/08 crisis provide the most comprehensive case on how deregulation can backfire. Equally, unserved demand, potential violation of human right to accessible legal services for all citizens as well as lack of corporate governance principles (Hauptman et al.,
2015) can cause substantial social costs in legal services market.

Surprisingly even some key contributors to the EU policy documents (Canton et al., 2014) provided only a biased view on professional services deregulation. They argued strongly that public professional services contain a certain risk to be captured (misused) by special interests of highly educated service providers or by autocratically inclined state. However, our precise analysis of Canton et al. (2014) disclosed various risks of over-generalisation. Nevertheless, a vocal and clear support for public good status of legal services comes from the European Court of Justice (ECJ, 2006) which concluded "... first, the protection of consumers, in particular recipients of the legal services provided by persons concerned in the administration of justice and, secondly, the safeguarding of the proper administration of justice, are objectives to be included among those which may be regarded as overriding requirements relating to the public interest capable of justifying a restriction on freedom to provide services". Fortunately, more holistic sources (Hadfield, 2000; Copenhagen Economics, 2005; Paterson et al., 2007; Barone et al., 2010; Garoupa, 2014) offer a nuanced and critical view. However, exhaustive analysis of legal services submarkets are particularly rare.

Reviewing the EU sponsored research on deregulation in services, we observe a disquieting lack of balance in argumentation (EC, 2017a). The main deregulation argument is reinforced with a couple of references and crude 
measures, which stretch very far from the core focus, but still support the deregulation ideal. Finally, regulation is discussed as an obstacle, which shall disappear, not bothering with market conditions justifying the regulation or whether it is still efficient in economic sense (Maheshri et al., 2014).

Our research attempts to address the contemporary knowledge gap in economic optimisation of regulation for the specific submarket of legal services for households and SMEs. We will demonstrate the fragile relation between market inefficiency and its specific remedies influencing social welfare of most vulnerable parts of society, which is often neglected (Garoupa, 2014; Hadfield 2014). Finally, a model for financially viable network coverage is developed and tested on Slovenian population data to address physical and economic accessibility of specific credence goods.

In order to achieve our goal, we analyse the impact of legal market deregulation in several EU countries and explain the phenomena by introducing a basic regulation curve model based on the market inefficiency-remedy relation. In addition, we presented the results of a longitudinal study of Slovenian legal offices population for the period 1995-2014 to demonstrate how imprudent regulatory interventions paradoxically hurt those market participants who were supposed to be protected.

\section{Legal Services Market Inefficiency: Literature Review}

Collecting relevant information in the market enables consumers to make informed decisions, but in many cases, quality of goods is not easily observable. Nelson (1970) distinguished between search and experience goods. Quality information of a good is either searchable before the purchase or we have to use it first to experience the quality. Darby et al. (1973) amended Nelson's idea with third class of goods, termed credence goods that are difficult to evaluate even after the use due to lack of professional knowledge. Unless some quality assurance instrument convincingly separates quality goods from lemons, customers become reluctant to pay for it and adverse selection will lead to a downward spiral of average quality (Akerlof, 1970).

The principal-agent relationship between client and lawyer opens an additional dimension of information asymmetry, known as moral hazard. With an unclear pricequality relation desired by the client, the agent can be tempted to over-sell the quantity and quality of services (e.g. a contract or litigation). However, the final legal consequence for the customer will be known only after a considerable period. Moral hazard risk is mostly relevant for the segment of occasional private clients and SMEs (less informed and more price sensitive).

Legal services together with their systemic importance and credence status are exposed to causing sizable externalities. High quality legal services efficiently solve legal issues of clients and contribute to increasing legal certainty in a branch of law. A contribution to efficient administration of justice and increased legal predictability both display valuable externalities. The importance of property and contracting right for economic development was perfectly explained by Adam Smith (2017):
"Commerce and manufacturers can seldom flourish long in any state which does not enjoy a regular administration of justice, in which the people do not feel themselves secure in the possession of property, in which the faith of contract is not supported by law, and in which the authority of the state is not supposed to be regularly employed in enforcing the payment of debts from all those who are able to pay."

What seems like an intuitive truth turned out to be a hard nut to crack in theoretical sense. Endogeneity problem and long-term effects (Glaeser et al. 2004; Rodrik et al. 2004; Acemoglu, 2006) plague the mechanics of institutions and economic growth. However, the role of institutions became a key issue for economists in the last decades. The Word Bank introduced the Worldwide Governance Index (WGI) in 1996 to monitor institutional impact.

Public good is the opposite of private good: it is nonrivalrous and non-excludable. The idea is accredited to Samuelson (1954), who used the term collective consumption goods. It means that individual's consumption of such goods causes no reduction of utility for any other individual and even for non-paying individuals who cannot be excluded from consumption. Public good in pure theoretical meaning reduces transaction costs and creates positive externalities for the whole society. In order to avoid the well-known "tragedy of the commons" problem caused by under-production of a public good, the state has to establish provisions to guarantee public services on a viable basis (regulating or producing the public good itself). Health services, pharmacy and legal services probably come closest to the definition of public goods constituting a sustainable infrastructure for economic development. Their systemic impact is mainly acknowledged on the (visible) curative level, although the prime economic impact ascends from preventive and catalyst effects.

It is impossible to evaluate regulation's economic impact without a thorough analysis of perceived market inefficiencies in specific market circumstances. Thus, various authors (e.g. Stephen, 2006; Garoupa, 2014; Hadfield, 2014) indicated the weaknesses of a narrow focus on evaluation of particular instruments and overgeneralisation of research results for professional services. A well-functioning legal system facilitates smooth economic activity and according to Yarrow et al. (2012), it is a false conclusion that rules restricting conduct also tend to restrict markets and competition.

Based on empirical evidence from ever more integrated EU markets, we conclude that some highly resistible market inefficiencies might be at work in most EU markets for legal services. Unfortunately, legal services market did not attract much theoretical attention in the past (Philipsen, 2010). Therefore, we will use some parallels with similarly heavily regulated market for health care services. In his seminal work, Kenneth Arrow (1963) started the first attempt to describe health care market inefficiencies in a systematic manner.

Both pharmacy and legal services market exhibit commonalities, which can be hardly identified with other professional services in the statistical group (accounting, architecture or engineering). Many researchers (except Paterson et al., 2007 or Hadfield, 2014) neglect this opportunity for efficient economic comparison. Nonetheless, commonalities were elegantly used by the 
German BRAK association (Bundesrechtsanwaltskammer, 2010). They defended legal conformity of entry barriers to legal services market with the pharmacy market cases from the European Court of Justice (C-531/06, C-171 and 172/07). These cases convinced the ECJ to use the argument of general interest also in the case of legal services, which should guarantee a "healthy" functioning of the legal system.

The most attention-grabbing collection of overemphasized deregulation effects can be found in EC (2013) document and in Canton et al. (2014). The EC (2013) document deals with broader issue of professions entry barriers, which presumably hamper the employment and economic growth. In the studies review chapter only positive aspects of deregulation are discussed, vaguely mentioning some limitations. In order to prove their case, some US studies are quoted from beginning of 1980's and an impressive but unpersuasive employment growth effect of $+20 \%$ promotes the less regulated US states. However, only by reading the original source (Kleiner, 2006), you will find much more differentiated conclusions (based on 19902000 sample) together with a discussion on minimal professional standards needed to serve the public.

Described pattern is repeated in Canton et al. (2014) who tried to evaluate the economic impact of professional services liberalisation. Gathering empirical evidence they acknowledge the deficit of EU based studies, but later expose Pagliero (2011), stating that he rejected the welfare maximisation hypothesis in favour of capture theory. Again, we have to read the original to understand various limitations of Pagliero's contribution based on a sample of 448 observations in US and focused on estimating the objective of professional licensing boards. Finally, Pagliero (2011) correctly states that it is his first attempt, thus "the results should be taken with caution".

Regulation impact for any market is usually discussed passionately between two biased camps that like to overgeneralise. Consequently, a thorough and cautious analysis of existing literature for legal services market is necessary.

\section{Data and Methodology}

Our scope of research is focused on legal services market limitations of contemporary research and tries to suggest a regulation curve model for proper analysis of costbenefit relation for the social welfare. Additionally, we perform a financial viability analysis of legal office's business models, which is limited to Slovenian regional markets. The most representative EU countries from EU15 group and from ex-transitions countries were selected on the basis of data availability for economic restrictiveness.

Reliable population data for the regional legal services markets in Slovenia originate from the Financial Administration of Republic of Slovenia (FURS) and from the national Agency for Public Legal Records and Related Services (AJPES). We used the combined dataset for the period 1995-2014 with 18991 observations, which allowed us to observe basic financial data (revenue, costs, profitability and employees), legal form and location.

We used a time-series analysis of legal offices to evaluate long-term financial viability of their business models under existing regulation. A precise market segmentation approach within the legal services allows to identify and locate market inefficiencies within 3 size classes of legal offices.

\section{EU Trends in Professional Services Regulation}

EU member states adopted the Professional Qualification Directive in 2005 and the Service Directive in 2006 (Terry, 2009; Philipsen, 2010). However, Monteagudo et al. (2012) noticed that the deregulation directives chiefly failed to reduce barriers for legal services (even among the best 5 countries) and Terry et al. (2012) elaborated on their fast pace of changes. Single Market Strategy for goods and services (2015) and Guidance on reform needs (2017a) provided fresh deregulation guidance. Unfortunately, the EU sponsored documents treat deregulation superficially as a general remedy for initiating growth and job creation. Critics could claim this as an evidence for the private capture hypothesis in legal services market, but the case of Slovenia shall illustrate the need for detailed market analysis before forming final conclusions.

Considering the market characteristics of each professional service and comparative differences in their liberalisation pace, we observe a rather strong deregulation process since 1998, with legal services least effected. The highest deregulation potential was identified among regulation prone countries like Austria, Germany and Italy. OECD's Product Market Regulation indicator (PMR ranges from 0- least to 6-most restrictive), used for professional services, had reached levels of 4 or even 5 (e.g. accounting in Germany or architects in Italy) before the reforms started (Figure 1). This way PMR's weakness becomes evident, because it aims only at measuring the level of regulation but fails to explain its economically desirable level.

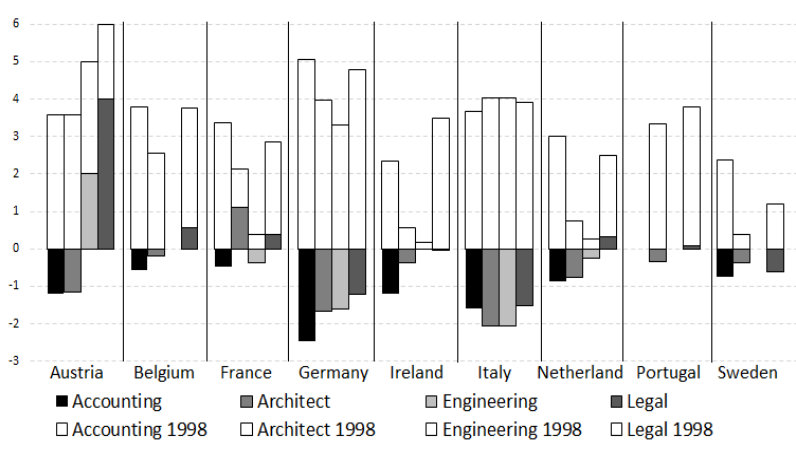

Figure 1. PMR Indicator Level for Professional Services in 1998 and Reform Impact Until 2013 (Data from OECD, 2017)*

* Deregulation produces a negative column value and vice versa. Empty columns denote PMR indicator value in 1998.

National legal services markets across developed EU economies revealed predominantly high PMR values between 3 and 5 (except Sweden) and began to lower them slowly. Quite the opposite happened in countries like Netherlands, Belgium and France, which increased the regulation levels slightly. The comparison with some posttransition countries in EU confirms the variety of legal market regulation levels, but in most cases, they seem to be at least as conservative as France or Germany (comparing 1998 with 2013). 
Data from some developed and post-transition EU countries indicate that the deregulation expectations for legal services were over optimistic (Figure 2). One reason is the undifferentiated treatment of legal services within professional services group. The second reason lies in the weakness of PMR indicator methodology, which fails to account for the "market inefficiency-remedy" relation.

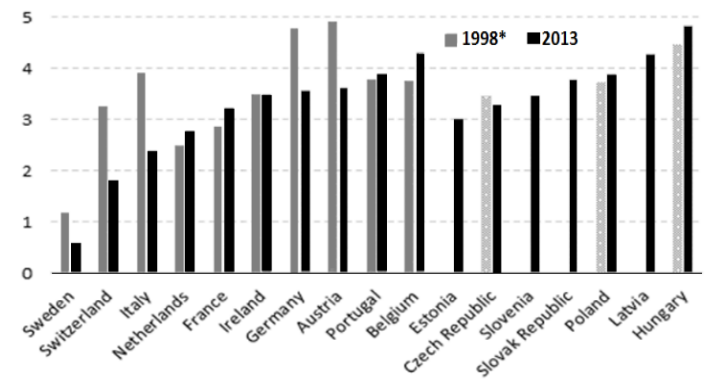

Figure 2. Regulation Indicator (PMR) for Legal Market Services (Data from OECD, 2017)

* Some post-transition EU countries provided comparable data for 2003 and 2013.

New restrictiveness indicator used by EC (2017b) has many similarities with the OECD's PMR. It takes into account only regulatory barriers of multiple requirements for the seven groups of professional services in order to support EC's qualitative analysis. The scale from 0 to 6 which is attributed for every restriction and later weighted. Restrictiveness indicator for legal services demonstrates a relatively high level in most EU countries (even in Sweden) (Figure 3). However, this is probably a direct consequence of inherent market characteristics causing permanent inefficiencies.

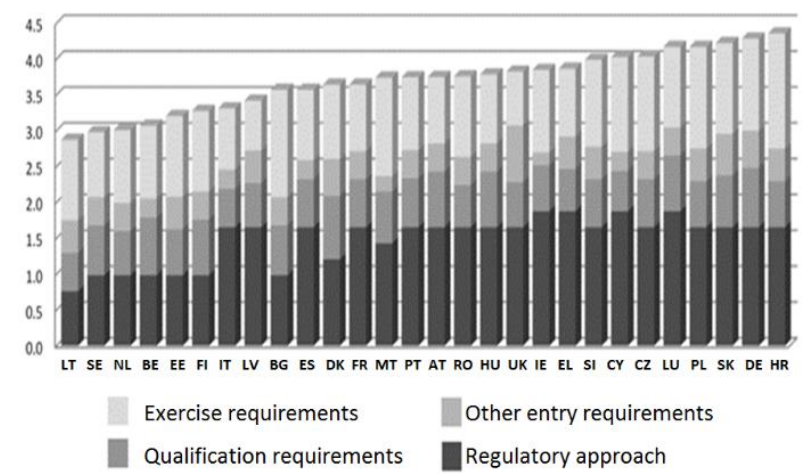

Figure 3. New EC's Restrictiveness Indicator - Lawyers (EC, 2017a)

Many deregulation-promoting researchers ignored the fact of actually two legal markets co-existing. The market for legal services is highly polarised, therefore the analysis of economic impact of regulation has to focus on providers catering to individuals and SMEs. Global experience from financial services market confirms that deregulating inefficient markets can cause long-term harm to clients, providers and the public at large. Without proper regulation, these market failures would directly hurt all market participants, but mostly the vulnerable bottom of the market (individual citizens and SMEs). Thus, the arguments will remain valid until the strong information asymmetry and externalities in legal services market persist.

\section{The Regulation Curve Model}

Our research follows the public interest theory of regulation, which aims at maximising social welfare based on thorough understanding for market inefficiencies and marginal remedy effects. The resulting cost-benefit summary shall be an objective criterion for changing or introducing regulation.

The majority of markets for search and experience goods have to deal only with basic regulations like product safety and information requirements on the product. Naturally, these goods will have a shorter regulation curve and reach the neutral regulation level (point $\mathrm{N}$ ) very quickly due to low level of information asymmetry and externalities (Figure 4). The point of optimal regulation (point O) lies relatively close to the point $\mathrm{N}$, but any additional regulation would swiftly start to produce negative marginal effects for social welfare.

For credence goods, the neutral regulation point will be higher on the regulation axes due to substantial damage in case of efficient regulation absence. With more complex markets, we face a higher probability that the point of optimal regulation $(\mathrm{O})$ is a moving target in the dark. Therefore, we have to learn from similar markets and continuously monitor regulatory impact in order to understand the assumed position on the regulation curve. Otherwise, we risk finding out that we are actually moving towards the exemplary point $\mathrm{D}$ (overregulation).

It is crucial to estimate the actual position on the curve to understand which way and why the regulation should change. Observing financial services before 2007/08, many experts of the liberal sort argued for deregulation, assuming the situation beyond the point D. However, it turned out that the regulation was too lax due to unobserved changes in market practices and products.

Estimating the difference between actual and optimal regulation levels is still difficult for credence goods. This theoretical difference indicates potential damage to social welfare and is the result of our ignorance for possible negative future scenarios. Consequently, we have to use bottom-up approach of (re)building our regulation network continuously, thus exploring the unknown terrain ahead. This meticulous task requires precise microeconomic knowledge of all market components concerned.

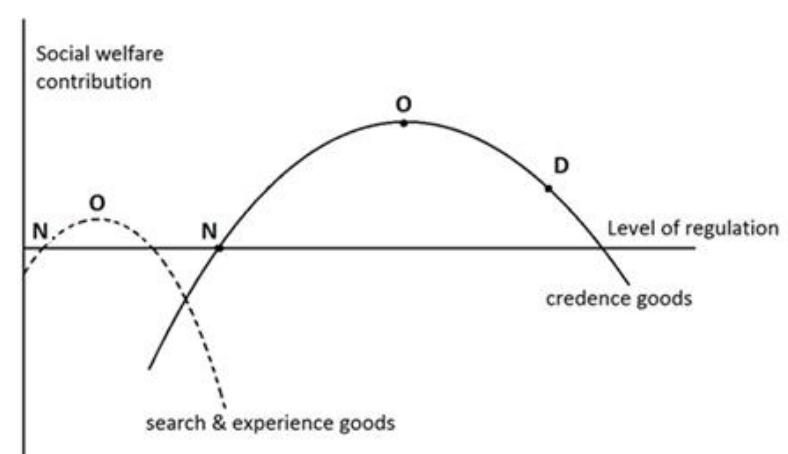

Figure 4. Regulation Curve Model 
Cumulative measure of economic restrictiveness (e.g. PMR or Restrictiveness index) shall not be treated as legitimate goals for minimization, because they are only a signal for remedies used, but do not provide any information on their benefits. Every regulation has to be assigned precisely to the market inefficiency and continuously tested for its impact, at the same time monitoring shifting market circumstances.

\section{Legal Services Market in Slovenia}

The legal services market in Slovenia has been developing since 1993 under market conditions based on the Attorneys Act. Standard market restrictions governed the national market for legal services in over two decades. The market enjoyed a steady growth, but the government's policy and changing market conditions with EU accession contributed to its polarisation and low network coverage at the bottom segment. Unfortunately, no attempt for a comprehensive analysis of the legal services market nor an economic impact analysis emerged during this period.

Poor information background and political calculation led to unfavourable consequences after the government effectively froze the lawyer's tariff (price list) in the year 2003. Therefore, we use the Slovenian case for illustrating the need for bottom-up analysis of a specific market with various forms of inefficiency. We emphasise the importance of a microeconomic market analysis before discussing changes in regulation, in order to understand the market inefficiency-remedy relation. At the same time, it is an opportunity for testing the private capture hypothesis on legal services market.

\section{Institutional Framework in Slovenia}

Attorneyship is prominently positioned within the Slovenian legal system. Chapter IV of the Constitution Act, titled "Organisation of the state", encompasses the article 137, defining attorneyship and notariat. It states clearly, "Attorneyship is an independent service within the system of justice, and is regulated by law" (OGRS, 2013). Moreover, the Constitution pledges equal protection of rights (article 22), under which everyone shall be guaranteed equal protection of rights in any proceeding before a court and before other state authorities, local community authorities, and bearers of public authority that decide on his rights, duties, or legal interests.

The Attorneys Act from 1993 precisely defines all elements of lawyer's position in the legal system. It underlines that the lawyer shall be autonomous and independent in his practice (OGRS, 2016). For the purpose of this paper, we will summarise only the key elements from the Attorneys Act, which are detected by the restrictiveness indicator:

- Regulatory approach: access to profession is regulated by means of reserved activities and title protection (representation before courts and administrative authorities; drawing up legal documents, legal advice).

- Qualification requirements: 5 years university education in law and 4 years of relevant work experience (at least one year after passing the state exam), state exam.
- Other entry requirements: compulsory registration in the professional chamber; Slovene citizenship is required, active command of Slovene language, clean criminal record.

- Exercise requirements: only attorneys may be shareholders or owners of an attorney's office; incompatible activities include employment in the civil service (except for scientific, educational, artistic and publicist area), notarial activity; managerial functions other than authorised for attorneys; other tasks damaging reputation and independence of legal profession; indemnity insurance through the professional chamber, advertising restrictions and client's option to use the official tariff.

Attorneys Act includes traditional restrictions, which position Slovenian market close to the EU average according to EC's restrictiveness indicator (Figure 3). Presented portfolio of legal services restrictions for Slovenia is positioned among the top 1/3 of most regulated national markets in EU. Consequently, a highly regulated market for legal services like Slovenia, could provide the evidence for the private capture hypothesis. Considering the theoretical overview and some EU sponsored studies, we should be able to observe at least higher margins and wages. On the contrary, if our population data cannot confirm the former hypothesis, we might conclude that the restrictions are an adequate remedy for inherent market inefficiencies.

\section{Aggregate Market Analysis}

In 2004 Slovenia joined the European Union and in 2007 adopted EURO currency. GDP growth per capita jumped from 5.000 EUR in 1995 to over 18.000 EUR in 2015, reaching $83 \%$ of the EU28 average (expressed in PPP). It is an interesting fact that Slovenia has disproportionally high expenditures/capita for the justice system, close to levels of UK, Austria and Belgium (EC, 2016). Partly this is due to the fact that Slovenia maintains the highest number of judges per 100.000 citizens (around 44) in the EU and has at the same time one of the lowest numbers of lawyers on the same scale (around 79).

In 2015 Slovenia had 1.628 lawyers, organised in 1.300 legal offices. They are obliged to register and choose an appropriate status. Some 1.051 units were organised as liberal professions, 240 units as limited liability law firm, 4 units as a law firm with unlimited liability and 3 as subsidiaries of foreign law firms. Smallest legal offices with 0-1 employed represented $45.5 \%$ of all units and legal offices with maximum 3 people employed represented a big majority of $82.1 \%$. A certain market maturity effect is observable in the last group of 4+ employees, which increased from around 5\% in the 90's, and now approaching $20 \%$ of all legal offices. Altogether legal offices employed 3,418 people in 2015 . Our data show a steady growth of legal offices, corresponding almost perfectly to the number of new cases in courts (Figure 5). 


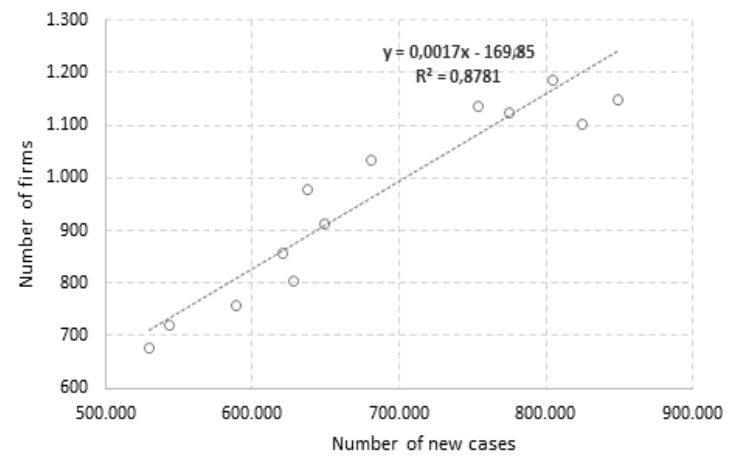

Figure 5. Correlation between New Cases in Courts and the Number of Lawyers (Data from FURS \& AJPES, 2016).

Total market value of legal services in 2014 amounted to around 162 mio. EUR which equals $0,43 \%$ of Slovenian GDP $(0,76 \%$ in Germany). Average margins decreased from around $31 \%$ (before EU accession in 2004) towards $24 \%$ after 2010. Market concentration increased after 1999 and almost doubled for the top 10 market players, reaching $22 \%$ in 2014. At the same time, the geographic concentration increased. Top 10 companies list in 2007 included law firms from Ljubljana, Maribor and Celje area, but in 2014 only one law firm among the top 16 was based outside Ljubljana.

Obviously legal services market is way different from accounting and other professional services. Therefore, an aggregate data analysis of Slovenian or any other legal services market would produce perfectly misleading conclusions. Basic descriptive statistic of our population of legal offices in 2014 shows a huge difference between the average revenue (126.805 EUR) and the median (55.884 EUR). Thus, we observe a highly positive asymmetric distribution of revenues with $77 \%$ of legal offices not reaching the average revenue. This is a strong signal for a highly polarised market with a few big law firms operating in the premium segment and the overwhelming majority at its bottom.

Due to our polarisation suspicions, we decided to split the lawyer's population into a few revenue based size classes in order to observe their business models sustainability. We were especially interested in business models for the smallest legal offices mainly organised as registered liberal professions. They are mainly a "one man band", often providing a network coverage of legal services for individuals and SMEs in less profitable areas. These people are typically a part of a crucial social fabric in smaller local communities without any expansion plans or aspirations to leave the area.

Within the revenue size classes, we aimed at observing the net profit margin (NPM) as a proxy for competition pressure and the viability of business models. We identified most interesting differences in NPM development among the 0-25.000 EUR, 25.000-50.000 EUR and about 50.000 EUR size class. Figure 6 shows that all the legal offices achieved almost similar performance in the period 19992003 when the lawyer's tariff followed inflation (NPM around $31 \%$ ). Competitive pressure is observable in a downward trend for all size classes, but after 2004, the smallest legal office start to diverge strongly from the rest.

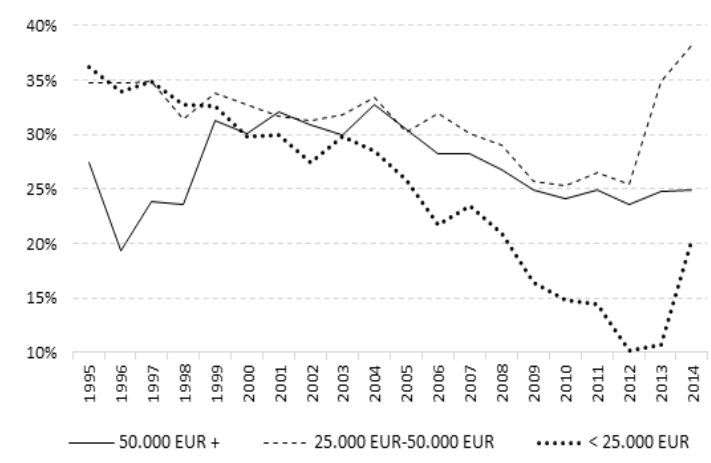

Figure 6. Net Profit Margin for three Revenue Size Classes in the Whole Population of Lawyers in Slovenia (Data from FURS \& AJPES, 2016)

Established vulnerability of the smallest legal service providers is a consequence of a limited portfolio dominated by low yielding services and provided for less sophisticated and less wealthy individuals and SMEs. Additionally, the business model, which provided a modest living before EU accession (average net salary was close to 600 EUR), did not have much reserve to compensate for the BalassaSamuelson effect. Consequently, the smallest legal offices (< 25.000 EUR) were economically destined for disappointment. At the same time the government decided to freeze the lawyer's tariff, thus stopping even the adjustment for inflation measured with CPI.

The same population data show a quite different story for the size class 25.000-50.000 EUR. The NPM is almost similar to the size group over 50.000 EUR, demonstrating the downward pressure. An unusual phenomena between the smallest size classes emerges in the years 2013 and 2014. The sudden increase in NPM is a consequence of the new tax regulation allowing all smaller companies to register under a special tax regime, where $70 \%$ of revenues automatically becomes tax-deductible costs. Especially for services, this gives a big boost to NPM. However, the Figure 6 also demonstrates the injustice of such interventions. On one side, we have the smallest legal offices not fully compensated for unjustly low prices in lawyer's tariff, but at the same time, the next size class receives an undeserved tax gift.

\section{Legal Services Portfolio}

Ideally, a provider of legal services should compile a mixed portfolio of individual clients and some business clients. Long-term contracts with business clients and success fees would provide a secure fundament and better margins, thus the fluctuations in individual clients segment could be easily managed. A lawyer lives from selling her hours and despite a falling trend in Slovenia, she could still earn 71.6 EUR/hour from bigger projects in 2014. If lucky with her portfolio, she could make 23.4 EUR per hour on average. However, effectively sold hours with smallest legal service providers reach only around $12.60 \mathrm{EUR} / \mathrm{hour}$.

In order to survive in such market circumstances a lawyer's effort is concentrated on finding cases, which are more profitable, and the rest of her time capacity is devoted to less profitable ones. The smaller cases are often unprofitable, thus a cross-subsidising process guarantees that even non-profitable services are offered to the clients. 
This phenomenon is well documented on the German legal services market. According to BRAK (2010) a geographic concentration of services contributes to further market polarisation, where the premium service providers have no need to cross-subsidise less profitable services. Yet, providers at the lover segments of the market might have some high-yielding services to support cross subsidising. However, almost $2 / 3$ of legal offices with 1 lawyer provided predominantly low-yielding services in 2012.

Smallest legal offices in Slovenia face a situation similar to Germany, where geographical concentration of most profitable cases is increasing. After the global crisis, the number of business clients decreased further (sold to bigger groups in Slovenia or abroad or even bankrupted). Consequently, the legal services portfolio structure deteriorated. Thus, the share of les wealthy clients who predominantly use the lawyer's tariff sharply increased, especially in less wealthy regions.

\section{Lawyer's Tariff}

Lawyer's tariff in Slovenia is suggested by the Bar Association and approved by the Minister of Justice. The tariff evaluates all lawyer's services, defines the calculation method and expenditures, which have to be covered by the client. Lawyer's services are evaluated with a stable system of points, thus it is crucial how the value of this calculative point is adjusted through time. The value of the tariff point is the key price control instrument in the hands of the government. It functions as the minimum price on the market for legal services. However, any lawyer can charge more if the client agrees in the form of a written contract.

Compulsory minimum tariff for lawyer's services seems to be a market conform solution. It seeks to ensure access to justice, protection of clients, prevention of price wars and deterioration of service quality, but most of all supports a proper administration of justice. Since 1991 the lawyer's tariff was adjusted only when inflation exceeded $10 \%$ p.a., but never for the full value of inflation loss (only around $85 \%$ ). This practice stopped in 2003, when the tariff point value reached 0,459 EUR and did not change until 2017 (Figure 7).

The main justification for effectively freezing the lawyer's tariff should be grounded on public service status or market failure in the form of abnormal returns. We have already proven in this paper that there is no evidence of abnormal returns in the relevant population. Additionally, we analysed potential economic barriers to justice for households in the period 2003-2012. We used the average household income and the average value of lawyer's hour sold in the market. The results clearly show that a household's buying power increased by $50 \%$ in the analysed period. Finally, in the whole period since 2003 the government nor the consumer protection associations used any similar arguments. The main reason freezing lawyer's tariff was a strong anti-inflation policy, which used price controls mechanism for $18 \%$ of goods and services before adopting the EURO.

Proper understanding of the so-called BalassaSamuelson effect should make the government aware that legal services relative prices will unstoppably adjust to the levels in the common EU market. Unfortunately, even after many years of low inflation, the responsible Minister still could not decide for an adjustment. The main reason lies in the nature of lawyer's business model. Lawyer's services are mainly the result of craftsmanship and less production. Consequently, even the most innovative and well capital equipped lawyer is not able to increase productivity by much. The cost structure in the whole population precisely shows the dominant share of labour costs which are growing in-line with wages in the more profitable and productive (tradable) sectors, competing for the well educated work force. Thus, lawyers as well as hairdressers or any other similar service cannot compete on productivity basis, but only on quality. Lacking internal reserves in the business model, the lawyers have to adjust their minimum prices at least as fast as competitive workplace wages.

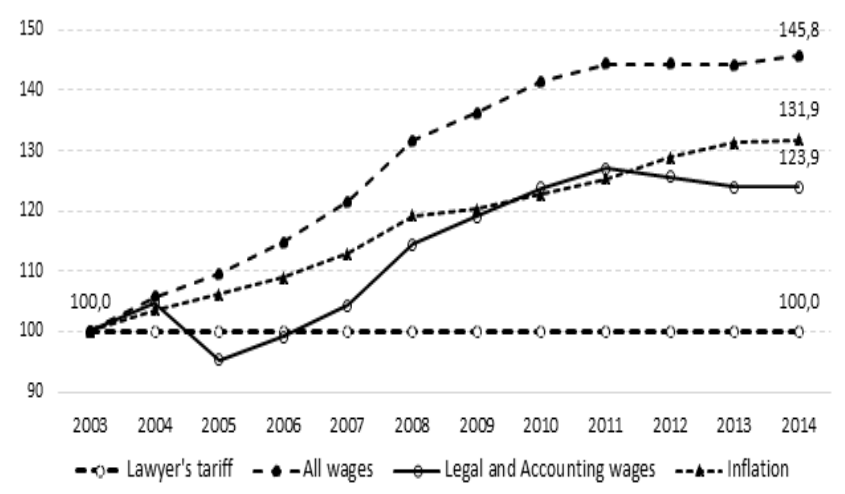

Figure 7. Disparity in Lawyer's Tariff Point Value, Wages and Inflation Growth Index (Data from SI-STAT)*

* Base year 2003

After observing all theoretically relevant parameters for adjusting a controlled price in the form of lawyer's tariff, we conclude that an effective freeze for the minimum prices is unjustified and potentially detrimental for a sustainable administration of justice and for the access to an appropriate level of legal service quality. The only identifiable (but professionally unacceptable) reason for the lasting lawyer's tariff freeze is a low public opinion of Slovenian justice system and some publicly exposed lawyers. Consequently, agreeing on an increase in lawyer's revenues is commonly an unaffordable political cost for the government.

\section{Legal Services Network Coverage}

Legal services are undoubtedly enabling a balanced economic development of modern societies. Access to justice, in both economic and physical terms, are commonly guaranteed by national constitutions and laws. Consequently, lawyers have to be accepted as an integral part of an efficient justice administration system and as an important point of first contact. Similar to health services, we should focus more on preventive effects of proper legal service, using its positive externalities for raising awareness of proper behaviour in legal relations. When fulfilling these noble aims, the Government should not forget to test the minimum economic conditions for maintaining an optimal network of legal services within a reasonably efficient market conditions. 
In order to guarantee a certain level of accessibility to justice in both economic and physical terms, we have to consider the network in regional markets for legal services. Our analysis on domestic regional populations shows a concentration of economic power in big centres, especially in the country's capital. With a low number of lawyers per 100.000 citizens in EU comparison, it is clear that the coverage ratio in economically poorer regions in Slovenia is deteriorating.

Economic reasons for a geographical concentration of legal offices is clear. They follow the bigger business clients and wealthy individuals in bigger centres. This top segment of the market is highly competitive, but it provides longterm cooperation possibilities and higher margins for complex legal cases. On the same regional market, there are also many small legal offices, not capable to compete for the high yielding complex cases, due to knowledge and reputation barrier. But then again, at least they have a high concentration of potential individual clients and SMEs of average wealth around them.

The worst market conditions persist in less wealthy regional centres and their periphery. For illustration purposes, we can report the data for lawyer's revenue per capita in certain regional centres in 2013: the values range from 19 EUR in Ptuj, 40 EUR in Celje, 56 EUR in Maribor and 153 EUR in Ljubljana. With adverse market conditions for the smallest legal services providers, we also observed an increasing level of market concentration. Thus, in Ljubljana the top 5 legal offices controlled only $19 \%$ of the reginal market, in Koper $42 \%$ and in Slovenj Gradec area even above $80 \%$. Unsurprisingly, the latter was the only area where net profit margins remained high for all size classes of legal offices.

We also examined the trends in legal offices profitability regardless of their size (Figure 8). For this purpose we constructed 4 classes of profitability measured by NPM: (i) negative; (ii) low $(0 \%-10 \%)$; (iii) middle (10 $\%-30 \%$ ) and (iv) high (above $30 \%$ ). Focusing on the smaller units with revenues up to 50.000 EUR, we discovered that the failure of adjusting the lawyer's tariff to the inflation rate since 2003 had an over-proportionally negative impact on legal offices predominantly acting at the bottom of the market.

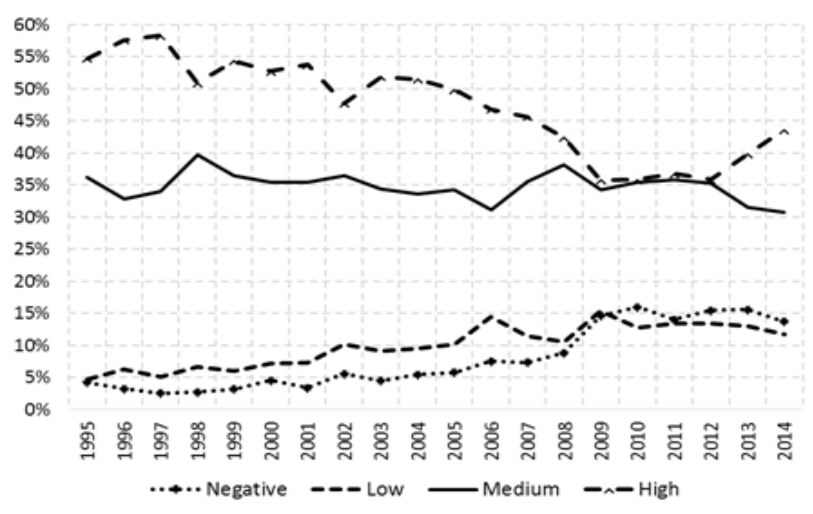

Figure 8. Share of all Legal Office Units Within a NPM Class (Data from FURS \& AJPES, 2016)

Our analysis presents a disquieting situation report on legal services market in Slovenia. The share of loss making units among the smaller participants increased sharply to around $15 \%$ and almost the same proportion achieved an unsustainably low profitability. Altogether almost $30 \%$ of legal offices, which are forming an already thin network for supplying legal services, seems to be economically endangered. Furthermore, when excluding 4 wealthier areas (LJ, NG, KP and CE), the share of endangered legal offices surges to almost $40 \%$ in 7 regions. Such circumstances directly endanger the capacity and density of a minimal legal services network in Slovenia. At the same time, dismal perspectives in lawyer's profession divert capable new students to start the career, causing long-term gap in labour supply, which cannot be filled quickly.

\section{Conclusions}

Despite the deregulation frenzy in EU professional services market, which was based on biased expert's anticipations, our analysis shows very limited benefits from reducing excessive regulation in a few national markets. The reason for this remarkable failure is twofold: (i) overgeneralised interpretation of positive deregulation effects in connection with (ii) a knowledge gap in economic optimisation of regulation for the specific submarket of legal services for households and SMEs.

Longitudinal population data from Slovenian legal services market (1995-2014) undermine key claims made by various independent and EC sponsored research contributions which are based on aggregate market data and overgeneralised conclusions from scientific literature. Researchers mainly failed to recognize the specific nature of legal services in a segmented and highly polarised market.

Our case based research provided a deep insight into the specific submarket of legal services for households as well as SMEs and managed to identify the main risks for the policy makers. Thus, we introduce a simple regulation curve model to demonstrate the economic impact of regulation, especially in the case of credence goods, which demand for a certain level of efficient regulation in order to prevent massive and long-term negative impact on public welfare. Our simple regulation curve model is based on specific "market inefficiency \& remedy" relation in order to expose the deficiencies of OECD and EC models, which are grounded on deficient variants of restrictiveness indexes. They aim at measuring the level of regulation, but fail to define its economically desirable level.

The systemic and long-term impact of legal services requires special attention to avoid two problems at the extremes: "tragedy of commons" and the "private capture" problem. Their public good status is a real-world fact confirmed by national constitutions, laws and even by decisions of the European Court of Justice. Thus, the key elements of regulation should support financial viability of relatively small service providers, who are crucial for proper network coverage outside big centres.

Slovenian market for legal services holds some useful lessons for other markets with distorted regulation balance. A strongly positive asymmetric distribution of revenues unveiled that $77 \%$ of legal offices did not reach the population average. Additionally, an unsustainable gap in net profit margins after the lawyer's tariff freeze in 2003 and 
a strong geographic concentration became obvious. Moreover, after excluding 4 wealthier regions, the share of endangered legal offices surges to almost $40 \%$ in 7 regions. At the same time, dismal perspectives for lawyer's profession divert capable new entrants from starting the career.

Understanding the fine fabric of legal services market is the key to efficient regulation warranting potent remedies for information asymmetries, externalities and public good status. Any aggregate treatment of regulation is potentially futile at best and hazardous at worst. Each regulation instruments has to be simulated separately on microeconomic data level in order to estimate the economic impact for the public welfare. Freezing the lawyer's tariff since 2003 in the case of Slovenia paradoxically hurt smallest legal offices with low yield service portfolios, which are helping to maintain government's promise of physical and economic accessibility of legal services for most vulnerable groups. However, only slow recovering of lawyer's tariff can be expected due to political costs and the fiscal effect for the budget.

Future research shall concentrate on modelling the minimum requirements for financially viable legal services providers who are maintaining an efficient network coverage. Additionally, a collection of cases analysing economic effects of particular remedies for legal services market inefficiencies in various countries should provide a summary of best and worst practices. Only on this basis we will be able to form more generally reliable conclusions.

\section{References}

Acemoglu, D. (2006). Modelling inefficient institutions. In Advances in Economic Theory. Proceedings of 2005 World Congress. Cambridge University Press. UK.

Akerlof, G. (1970). The market for "Lemons": Quality Uncertainty and the Market Mechanism. Quarterly Journal of Economics, 84(3), 488-500. https://doi.org/10.2307/1879431

Arrow, K.J. (1963). Uncertainty and the welfare economics of medical care. The American economic review, 53(5), 941-973.

Barone, G. \& Cingano, F. (2011). Service regulation and growth: Evidence from OECD countries. The Economic Journal, 121(9), 931-957. https://doi.org/10.1111/j.1468-0297.2011.02433.x

BRAK - Bundesrechtsanwaltskammer (2010). Positionspapier der Bundesrechtsanwaltskammer zum Thema: Europarechtskonforme Beschränkungen für die Zulassung zum Beruf des Rechtsanwalts. Erarbeitet vom Ausschuss: Deregulierung und Wettbewerb. Oktober. Available from internet: https://www.brak.de/w/files/01_ueber_die_brak/02_05_37_BRAKPosPapierZulRABeruf.pdf

Canton E., Ciriaci D., \& Solera, I. (2014). The economic impact of professional services liberalisation. Economic papers 553. EC - DG ECFIN. Brussels, 3.3.2010. COM(2010) 2020 final. Available from internet: http://ec.europa.eu/economy_finance/publications/economic_paper/2014/pdf/ecp533_en.pdf

Coase, R. (1988). The Firm, the Market, and the Law. The University of Chicago Press. Chicago.

Copenhagen Economics (2005). Economic assessment of barriers to the internal market for services. Final report. Available from internet: https://www.copenhageneconomics.com/dyn/resources/Publication/publication PDF/4/124/0/trade4.pdf

Darby, M.R., \& Karni, E. (1973). Free competition and the optimal amount of fraud. The Journal of Law and Economics, 16(1), 67-88. https://doi.org/10.1086/466756

EC. (2005). Directive 2005/36/EC of the European Parliament and of the Council of 7 September 2005 on the recognition of professional qualifications. Official Journal of the European Union.

EC. (2006). Directive 2006/123/EC of the European Parliament and of the Council of 12 December 2006 on services in the internal market. Official Journal of the European Union.

EC. (2013). Communication from the Commission to the European Parliament, the Council, the European Economic and Social Committee on Evaluating national regulations on access to professions. Brussels, 02.10.2013. $\operatorname{SWD}(2013) 402$ final.

EC. (2016). Study on the functioning of judicial systems in the EU Member States - Facts and figures from the CEPEJ questionnaires 2010-2012-2013-2014. CEPEJ. Strasbourg, 14 March 2016.

EC. (2017a). Communication from the Commission to the European Parliament, the Council, the European Economic and Social Committee and the Committee of the Regions on reform recommendations for regulation in professional services. Commission staff working document. Brussels, 10.01.2017. COM(2016) 820 final. 
EC. (2017b). Communication from the Commission to the European Parliament, the Council, the European Economic and Social Committee and the Committee of the Regions on reform recommendations for regulation in professional services. Commission staff working document - Accompanying the document. Brussels, 10.01.2017. COM(2016) 820 final.

ECJ. (2006). Cipolla vs. Portolese. Judgement of the Court (Grand Chamber). Paragraph 64.

Friedman, M. (1962). Capitalism and Freedom. University of Chicago Press.

Garoupa, N. (2014). Globalization and deregulation of legal services. International Review of Law and Economics, 38, 77-86. https://doi.org/10.1016/j.irle.2013.07.002

Glaeser, E.L., La Porta, R., Lopez-de-Silanes, F., \& Shleifer, A. (2004) Do institutions cause growth? Journal of Economic Growth, 9(3), 271-303. https://doi.org/10.1023/B:JOEG.0000038933.16398.ed

Hadfield, G. K. (2000). The price of law: How the market for lawyers distorts the justice system. Michigan Law Review, 98, 953-1006. https://doi.org/10.2307/1290336

Hadfield, G. K. (2014). The cost of law: Promoting access to justice through the (un)corporate practice of law. International Review of Law and Economics, 38, 43-63. https://doi.org/10.1016/j.irle.2013.09.003

Hauptman, L., \& Belak, J. (2015). Ethical tax corporate governance of state-owned enterprises. Systems Research and Behavioural Science, 32(2), 183-189. https://doi.org/10.1002/sres.2258

Kaufmann, D., Kraay A., \& Mastruzzi, M. (2010). The worldwide governance indicators: Methodology and analytical issues. Global Economy and Development. Brookings Institute.

Kleiner, M. M. (2006). Licensing Occupations: Ensuring Quality or Restricting Competition? Kalamazoo, Michigan: W.E. Upjohn Institute for Employment Research. https://doi.org/10.17848/9781429454865

Lee, R. G. (2010). Liberalisation of legal services in Europe: Progress and Prospects. Legal studies, 30(2), $186-207$. https://doi.org/10.1111/j.1748-121X.2009.00148.x

Maheshri, V., \& Winston, C. (2014). An exploratory study of the pricing of legal services. International Review of Law and Economics, 38(S), 169-173.

Monteagudo, J., Rutkowski, A., \& Lorenzani, D. (2012). The economic impact of the Services Directive: A first assessment following implementation. Economic paper 456. DG ECFIN. Brussels, June 2012. Available from internet: http://ec.europa.eu/economy_finance/publications/economic_paper/2012/pdf/ecp_456_en.pdf

Nelson, P. (1970). Information and consumer behaviour. Journal of Political Economy, 78(2), 311-329. https://doi.org/10.1086/259630

OGRS. Official Gazette RS. (2016). Attorneys Act. Nos. 18/93, 24/96 - odl. US, 24/01, 54/08, 35/09, 97/14, 8/16, 46/16. Available from internet: http://pisrs.si/Pis.web/pregledPredpisa?id=ZAKO265

OGRS. Official Gazette RS. (2013). Constitution of the Republic of Slovenia. Nos. 33/91-I, 42/97, 66/2000, 24/03, 69/04, 68/06, and 47/13. Available from internet: http://www.us-rs.si/en/about-the-court/legal-basis/

Pagliero, M. (2010). What is the objective of professional licensing? Identification of a static model of licensing and some evidence from the US market for lawyers. International Journal of Industrial Organisation, 29(4), 473-483. https://doi.org/10.1016/j.ijindorg.2010.09.002

Paterson, I., Fink, M., Ogus, A., Merz, J., Fink, F., \& Berrer, H. (2007). Economic impact of regulation in the field of liberal professions in different member states. ENEPRI-European Network of Economic Policy Research Institutes. Working Paper No. 52/07. Available from internet: https://www.ceps.eu/system/files/book/1455.pdf.

Philipsen, N. J. (2010). Regulation and competition in the legal profession: Developments in the EU and China. Journal of Competition Law and Economics, 6, 203-231. https://doi.org/10.1093/joclec/nhp009

Rodrik, D., Subramanian, A., \& Trebbi, F. (2004). Institutions rule: the primacy of institutions over geography and integration in economic development. Journal of Economic Growth, 9(2), 131-165. https://doi.org/10.1023/B:JOEG.0000031425.72248.85

Samuelson, P. A. (1954). The pure theory of public expenditure. The Review of Economics and Statistics, 36(4), 387389. https://doi.org/10.2307/1925895

Smith, A. 1723-1790 (2017). The wealth of nations; Published by BookRix. 
Stephen, F. H. (2006). The market failure justification for the regulation of professional service markets and the characteristics of consumers. In C. D. Ehlermann \& Atanasiu I., (Ed.), European Competition Law Annual 2004: The relationship between competition law and liberal professions (pp. 143-153). Oxford/Portland Oregon. Hart Publishing. Terry, L. S. The European Commission Project Regarding Competition in Professional Services. Northwestern Journal of International Law \& Business, 29(1), 1-118.

Terry, L. S., Mark, S., Gordon, T. (2012). Trends and Challenges in lawyer regulation: The impact of globalisation and technology. Fordham Law Review, 80(6), 2661-2684.

Yarrow, G., Decker, C. (2012). Assessing the economic significance of the professional legal services sector in the European Union. Regulatory policy institute. Available from internet: http://www.rpieurope.org/Publications/2012/RPI_study_Yarrow_D1_1348650358.pdf.

The article has been reviewed.

Received in January, 2018; accepted in June, 2018. 